\title{
Revisiting architectural landmarks
}

\author{
Natalia Kosenkova ${ }^{1 *}$, Denis Litvinov $^{1}$, and Yelizaveta Kosenkova ${ }^{1}$ \\ ${ }^{1}$ Samara State Technical University ofArchitecture and Civil Engineering Academy, 443001, 194, \\ Molodogvardeyskaya St., Samara, Russia
}

\begin{abstract}
This paper discusses the urban development history of Samara and the nuances of how its urban pattern was formed. The paper highlights the key milestones in the history of the city's development, addresses how the unplanned and planned cities were structured, and considers the city's main historic squares. It also analyzes the part the city squares play in modern Samara. The definition of the term architectural landmark provides the basis for several primary classifications of architectural landmarks, identifying the historic landmarks of Samara. Also considered is the part that the primary architectural landmarks played in forming the historical and modern urban environment as well as how that part changed as the city grew and developed. The paper also addresses the effect that later development has had on the historic landmarks. Keywords: city, urban development, architectural landmarks, city structure, planned city.
\end{abstract}

\section{Introduction}

The urban development history of Samara spans over 400 years. The history is divisible into the following periods: 1) the oldest period; 2 ) the period of the first state formations; 3 ) the Russian colonization period in the sixteenth-seventeenth centuries; 4) the eighteenth century (the strengthening of the Russian state); 5) the nineteenth through the early twentieth century: capitalization of the economy, the time when the architectural and historical environment of the near-Samara Volga region was formed as a whole; and 6) 1917-1980, the Soviet period.

What little has survived of the first two periods is chiefly limited to written records as the wooden buildings constructed in the early days of Samara history burned down. Most of the surviving listed and heritage buildings belong to the fifth period-the second half of the nineteenth century through the early twentieth century.

Samara started in the sixteenth century as a border fortress in the east of the Russian state. In the middle of the nineteenth century (1851), the fortress was raised to the status of Samara Governorate's principal city. From that time on, Samara began to develop dynamically.

The city boundaries were extended in keeping with the territorial and structural development of the city at different historical junctures [1]. The year 1782 saw the first Samara city

\footnotetext{
* Corresponding author: kosenkovana@mail.ru
} 
plan created, and in the early nineteenth century Samara started to develop as a planned city (fig. 1).

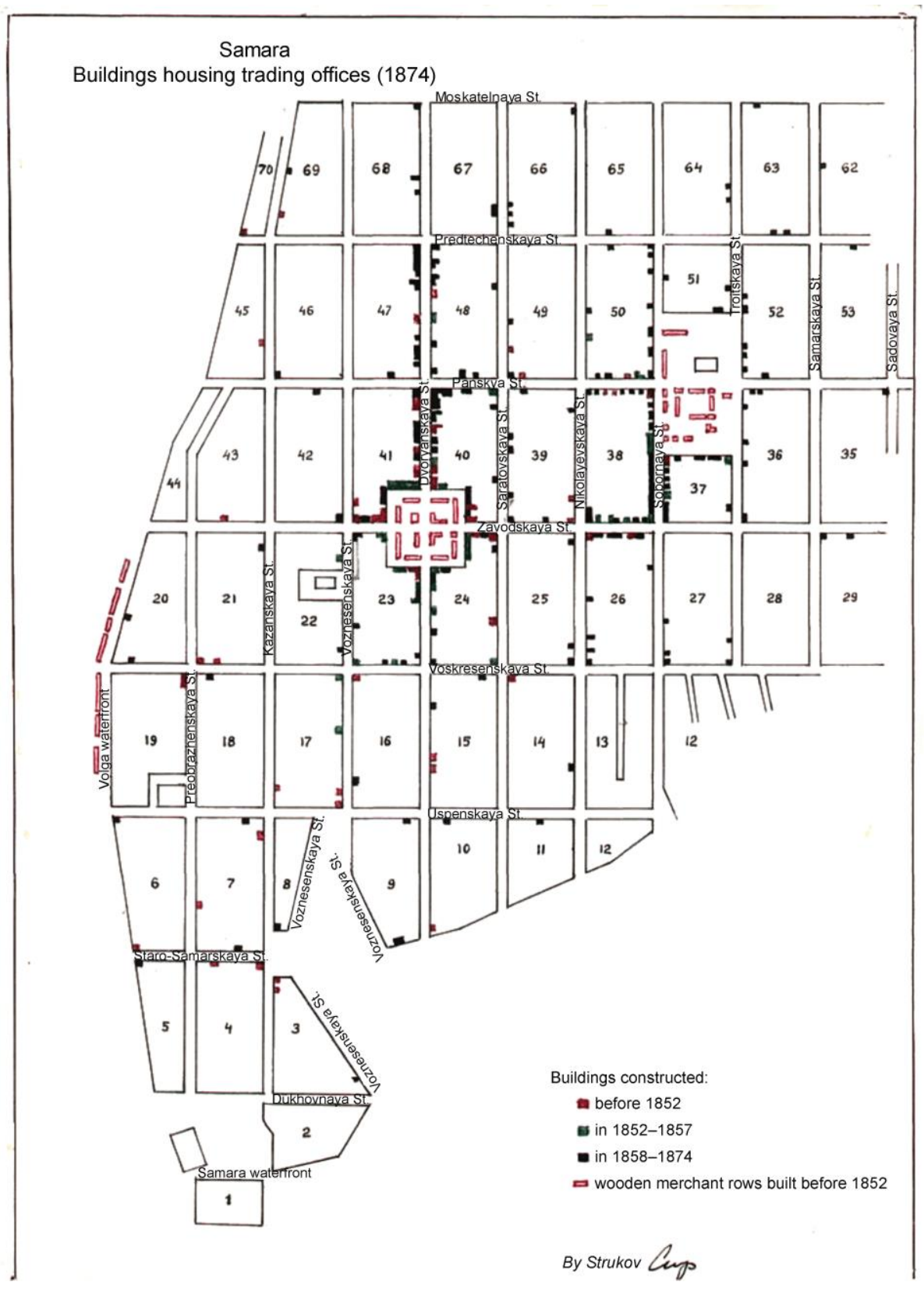

Fig. 1. Map of Samara. 


\section{City planning structure}

Today, Samara retains the planned city structure in its entirety. The few surviving unplanned spots indicate the directions of some old city streets.

The old city's longitudinal direction only had one full-fledged street, called Bolshaya (Russian for big). A length of it survives on Vodnikov Street and between Leningradskaya and Ventseka streets. The irregular shape of the oldest of the city's squares - Khlebnaya Sq. (formerly Politseyskaya Sq.) - is partly due to the proximity of city fortifications [2,3].

According to the plans of 1782 and 1804, the street system of the planned city developed in two directions: along the Volga at a small angle to its shoreline and in the direction perpendicular to the longitudinal streets that led from the city to the Volga and Samara rivers. According to the 1852 plan, the street grid in the area of Ulyanovskaya St. (former Simbirskaya St.) was dislocated as the city continued developing. Ulyanovskaya St. and Yarmorochnaya St., intersecting at an acute angle, marked the turn of all the longitudinal streets parallel to the Volga bank, which changes direction in that region.

Squares were a major component of the planned city structure. Extensive open spaces (Sobornaya Sq., 13 ha; Elijah Sq. and Petropavlovskaya Sq., about 7 ha each) added variety to the monotonous street system. Eight squares (elements) differing in construction dates, configuration, size, and functionality were evenly distributed across the city, most often at the intersection of the most important streets under favorable landscape conditions. The irregular shapes of the squares are due to the directions of the surviving unplanned city streets adjacent to them [4].

A characteristic feature shared by most of the squares was that they each had a church located centrally regardless of the square's purpose. When a cathedral was built in the city, Sobornaya (Cathedral) Square gained great importance. Thanks to its size and purpose, the place became the main religious square and spiritual center of the city in the $1880 \mathrm{~s}$.

Squares with a church in the center were named consistent with the name of the saint the church was dedicated to: the Square of Peter and Pavel (formerly Sennaya); Elijah Square (formerly Ostrozhnaya), Trinity Square, and the like. The technique of placing a church in the center of a square was widely used in the second half of the nineteenth century.

In the city's historic region, none of the squares that served as architectural and spatial emphasis have survived intact. Revolutsii (formerly Alekseyevskaya) Sq., Khlebnaya (formerly Politseyskaya) Sq., Samarskaya (formerly Voskresenskaya) Sq., and Kuibysheva (formerly Sobornaya) Sq. are the few Samara squares that retain most or some of their original appearance. None of the square churches have survived. The Church of Peter and Pavel is still standing, but its current surroundings are unacceptable for a religious building. Some of the squares that saw, in the Soviet period, functional, landscape, and architectural renovations became part of new architectural complexes (Kuibysheva and Samarskaya squares).

\section{Architectural landmarks}

Architectural landmarks represent one of the most important components that make the composition of a historic city unique and give it aesthetic value. Architectural landmarks are predominant buildings that are qualitatively different in their specifications and high artistic characteristics from regular buildings. An architectural landmark can be a group of buildings or an individual building. They play a major part in forming city outlines and panoramas [5]. This is especially true for cities that sit on the banks of large rivers or other bodies of water. Predominant heights close the perspectives of streets, lend originality and compositional integrity to city squares, and add sharpness and variety to streets lined with regular buildings $[6,7]$. 
As a rule, historic cities have whole systems of architectural landmarks that are hierarchically interdependent [8]. Depending on the proportional ratio of mass housing and verticals, primary and secondary landmarks are distinguished. The height ratio of regular buildings to secondary landmarks can be 1:2, 1:3, and sometimes even 1:4.

In the past centuries, landmarks of that kind primarily were religious buildings. Fire towers and water-pressure and chapel towers often served as city landmarks as well $[9,10]$.

Depending on where they are located in the city structure, Samara churches can be divided into those located [11]:

1. on main streets: the Assumption Church, the Ascension Church, the Iversky Convent, the Mariinsky Orphanage Church, the Kazan Edinoverie Church, and the Sacred Heart Church;

2. in city squares: the Cathedral, the Church of Elijah, the Church of Peter and Pavel, the Resurrection Church, the Holy Trinity Church, the Kazan Bogoroditsky Church, the Transformation Church, and the Smolensk Church;

3. in city cemeteries: the Church of All Saints and the Protection Church (its graveyard was later on made into a city garden);

4. in the peripheral streets and areas: the Jewish Synagogue, the Tatar Mosque, the churches in Zasamarskaya Sloboda and in the town of Zapansky, the Church of the Healer Panteleimon at the Zemstvo Hospital, the Nikolayev Male Monastery complex; and

5. several churches that were formerly located in the suburbs of Samara outside the planned city and that, because of their remoteness from it, had no effect on the volumetric and spatial composition of the city's historic district or on the view of the city from the Volga and Samara rivers.

City landmarks are also classifiable by the effect they have on the architectural composition of the city:

1. Landmarks that actively influenced the formation of city outlines and panoramas as seen from the Volga and Samara rivers (all churches and monasteries located at the watershed and on the Volga and Samara slopes)

2. Primary city landmarks, exceeding the others in height and outline complexity: the Cathedral with a bell tower 89 meters high; the 70-meter-high bell tower of the Iversky Convent; the 40-meter-high bell tower of the Kazan Edinoverie Church; and the Sacred Heart Church and the Lutheran Church, which enriched the city outlines with their spire-shaped forms

3. Landmarks that are centers of the architectural composition of city squares - for example, the Church of Peter and Paul, the Church of Elijah, the Resurrection Church, and the Cathedral

4. Bell towers of some churches that complete the perspectives of city streets (e.g., the Church of Peter and Paul, the Protection Church, the Church of All Saints, the Church of Elijah, and the Iversky Convent)

5. Some of relatively small, low-belfry churches located amid street buildings in small spaces on the corners of intersecting streets (the Assumption Church on the corner of former Uspenskaya and Preobrazhenskaya streets) or in the gap between residential buildings, slightly set back from the building line (the Mariinsky Orphanage Church)

Note that in addition to the landmarks, the large architectural complexes of the Iversky Convent, the Vakano Brewery, the drama theater, and some other buildings that stood out in that they used nonstandard architectural solutions played a major part in forming the original outlines and panoramas of the city [12].

Of the architectural landmarks that existed in Samara at the turn of the nineteenth and twentieth centuries, few have survived. None of the primary landmarks has survived (figs. 2 
and 3); of the secondary landmarks, the Church of Peter and Pavel, the Protection Church, the Lutheran Church, the Sacred Heart Church, and the Synagogue still exist (fig. 4).

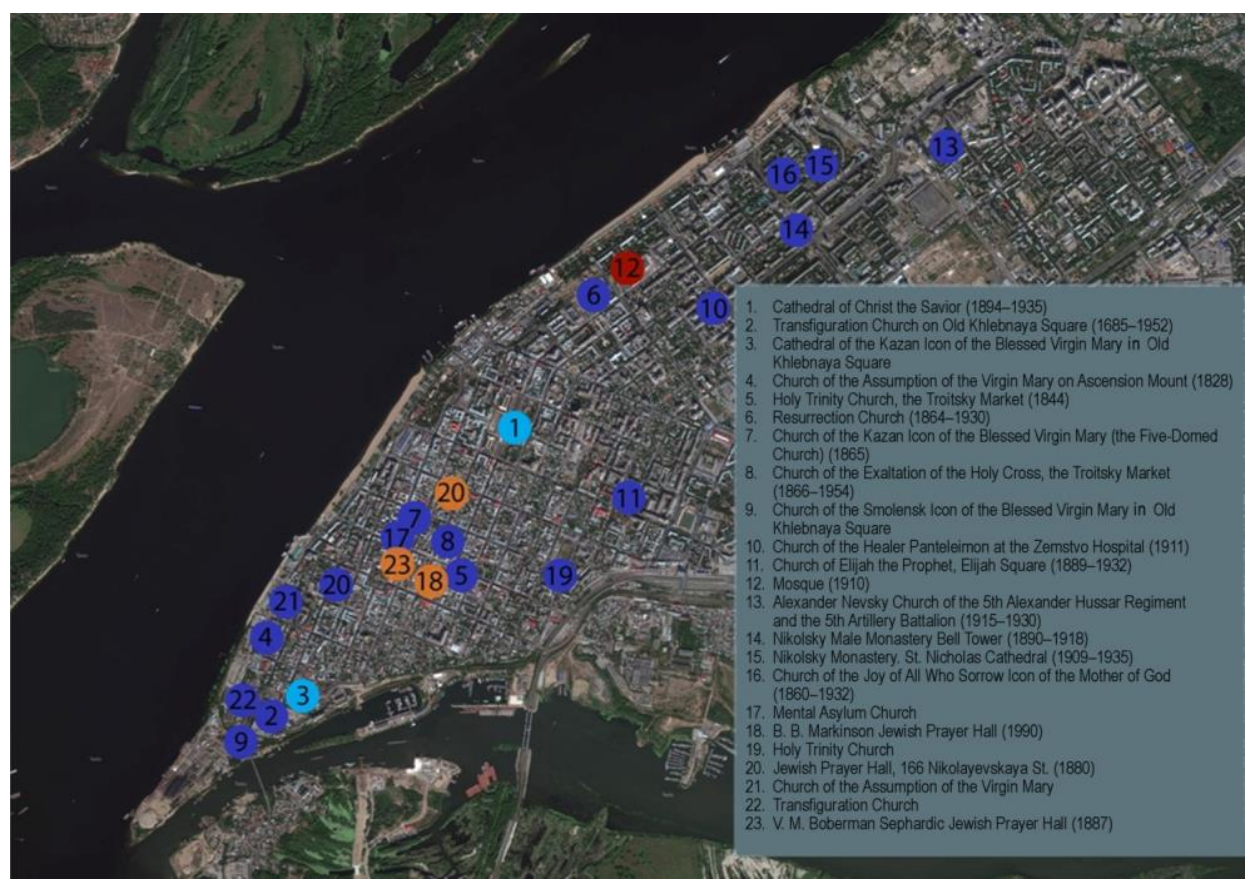

Fig. 2. Former architectural landmarks of Samara.

\begin{tabular}{|c|c|c|c|}
\hline $\mathrm{N}$ & Name & Years & Photo \\
\hline 1 & $\begin{array}{l}\text { Cathedral } \\
\text { of Christ the Savior }\end{array}$ & $1894-1935$ & \\
\hline 2 & $\begin{array}{l}\text { Transfiguration Church } \\
\text { on Old Khlebnaya Square }\end{array}$ & $1685 \cdot 1952$ & \\
\hline 3 & $\begin{array}{l}\text { Church of the Assumption } \\
\text { of the Virgin Mary on } \\
\text { Ascension Mount }\end{array}$ & $1828-1930$ & \\
\hline 4 & $\begin{array}{l}\text { Cathedral of the Kazan Icon } \\
\text { of the Blessed Virgin Mary } \\
\text { on Old Khlebnaya Square }\end{array}$ & 1744 - 1952 & \\
\hline 5 & $\begin{array}{l}\text { Holy Trinity Church, } \\
\text { the Troitsky Market }\end{array}$ & $1844-1933$ & \\
\hline
\end{tabular}

\begin{tabular}{|c|c|c|}
\hline N & Name & Years \\
\hline 6 & Resurrection Church & $1864-1930$ \\
\hline 7 & $\begin{array}{c}\text { Church of the Kazan Icon } \\
\text { of the Blessed Virgin Mary } \\
\text { (the Five-Domed Church) }\end{array}$ & $\begin{array}{c}1865- \\
\text { made into } \\
\text { theater in late } \\
\text { nineteen } \\
\text { century }\end{array}$ \\
\hline 8 & $\begin{array}{c}\text { Church of the Exaltation of the } \\
\text { Holy Cross, the Troitsky Market }\end{array}$ & \begin{tabular}{c}
$1866-1954$ \\
\hline 9
\end{tabular} \\
\hline $\begin{array}{c}\text { Church of the Smolensk Icon } \\
\text { of the Blessed Virgin Mary, } \\
\text { Old Khlebnaya Square }\end{array}$ & $1868-1952$ \\
\hline 10 & $\begin{array}{c}\text { Church of the Healer Panteleimon } \\
\text { at the Zemstvo Hospital }\end{array}$ & $1911-1930$ \\
\hline
\end{tabular}

\begin{tabular}{|c|c|c|}
\hline N & Name & Years \\
\hline 11 & $\begin{array}{c}\text { Church of Elijah } \\
\text { the Prophet, Elijah Square }\end{array}$ & $1899-1932$ \\
\hline 12 & $\begin{array}{c}\text { Third Parish } \\
\text { Cathedral Mosque }\end{array}$ & $1913-1963$ \\
\hline 13 & $\begin{array}{c}\text { Alexander Nevsky Church } \\
\text { of the 5th Alexander Hussar } \\
\text { Regiment and the 5th Artillery } \\
\text { Battalion }\end{array}$ & $1915-1930$ \\
\hline 14 & $\begin{array}{c}\text { Nikolsky Male Monastery, } \\
\text { the Bell Tower, } \\
\text { and St. Nicholas Cathedral } \\
\text { Church of the Joy of All Who } \\
\text { Sorrow Icon of the Mother of God }\end{array}$ & $1860-1930$ \\
\hline 15 & $\begin{array}{c}1860 \\
\text { now defunct }\end{array}$ \\
\hline
\end{tabular}

\begin{tabular}{|c|c|c|c|}
\hline $\mathrm{N}$ & Name & Years & Photo \\
\hline 16 & $\begin{array}{l}\text { Church of the Assumption } \\
\text { of the Virgin Mary }\end{array}$ & $1912-1969$ & \\
\hline 17 & Transfiguration Church & $\begin{array}{c}1860 \\
\text { now defunct }\end{array}$ & \\
\hline 18 & $\begin{array}{l}\text { B. B. Markinson } \\
\text { Jewish Prayer Hall }\end{array}$ & 1909 & $\begin{array}{l}\text { No photo } \\
\text { survived }\end{array}$ \\
\hline 19 & Mental Asylum Church & $\cdot$ & $\begin{array}{l}\text { No photo } \\
\text { survived }\end{array}$ \\
\hline 20 & Holy Trinity Church & - & $\begin{array}{l}\text { No photo } \\
\text { survived }\end{array}$ \\
\hline
\end{tabular}

Fig. 3. Former Samara temples. 


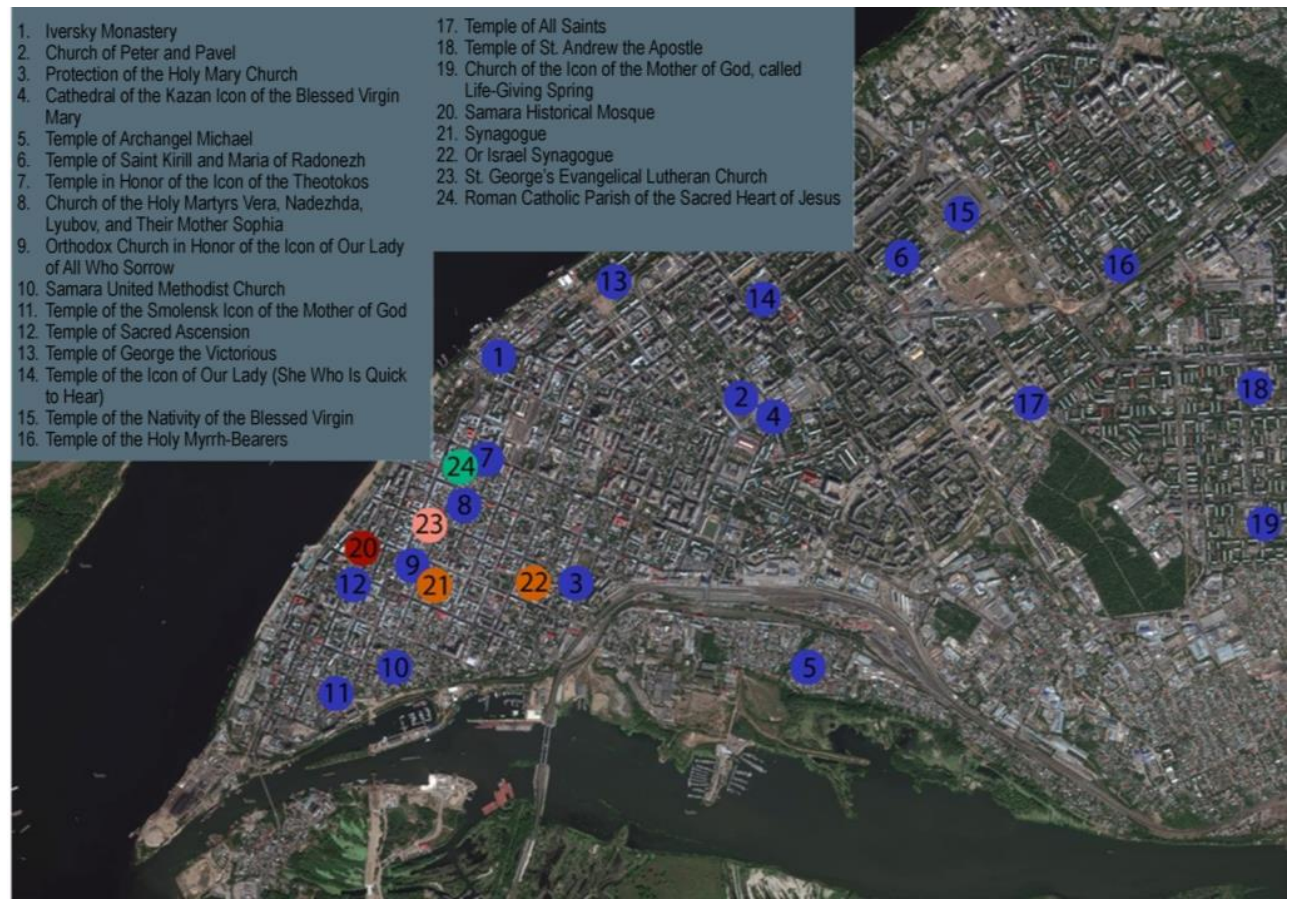

Fig. 4. Architectural landmarks of modern Samara.

As new buildings were built starting in the 1830s and most religious buildings were demolished, the city outline and panorama changed. Suppressed by the height and mass of the building of the House of Industry and by the extra stories added to some old buildings (an alteration unjustified as far as the city outline is concerned), the Lutheran Church and the Sacred Heart Church lost their importance as the leading architectural emphasis [13].

Clashing with the surrounding buildings and inconsistent with the panorama of the city's historic part is the dormitory of the military medical faculty.

The area between Ulyanovskaya and Polevaya streets was developed chiefly in the 1940s-80s. The architectural complexes of Samarskaya Square and the Square of Glory, the high-rise buildings on Polevaya and Mayakovskogo streets, and the regular buildings typical of the time form an outline that differs sharply in its scale from the historical outline.

The topographic map of Samara shows that the Church of the Icon of the Mother of God and the Temple of St. Andrew the Apostle are located on high terrain. The Temple of All Saints and the Temple of the Holy Myrrh-Bearers sit within the same horizontals and closer to a drop in the terrain. Placed that way, the temples are bright architectural landmarks, standing out from the surrounding buildings because of their prevailing aesthetic qualities and larger scale. The Iversky Convent and the Church of St. George the Victorious are located on the steep Volga slope, and they come across as architectural landmarks when looked at from the river. The sparseness of the surrounding buildings makes the temples stand out in the panorama of the city.

Looking at these and other examples of the existing religious buildings in Samara, we can conclude that the location of a building on the terrain also plays an important part. An advantageous position on the city terrain highlights the building and makes it clearly visible from several vantage points at once $[14,15]$. 


\section{Conclusions}

From our analysis of the history of Samara's urban development in the above-mentioned periods, we identified the architectural landmarks of the city. Their classification helped us determine their characteristic features and understand how their role changed over time as the city structure developed. The artistic expressiveness of buildings, their location in the city in relation to the natural landscape and to other buildings are the main criteria for the classification of architectural landmarks. Our retrospective analysis of large twentiethcentury architectural complexes showed that the arrangement of urban buildings has the greatest effect on how architectural landmarks are perceived.

\section{References}

1. M. Yakimov, Methods for spatial analysis of city structure distribution to estimate city agglomeration boundaries (2018).

2. T. S. Reshetnikova, Reconstruction of the remembrance: Palace of Culture in Slantsy. Frontiers of Architectural Research (2019)

3. T. Chen, C.M.Hui Eddie, Wu. Jiemin, Wei Lang, Xun Li, Наbю Int., 89 (2019)

4. Y. Lai, C. E. Kontokosta, Comp., Envir. Urb. Syst., 78, (2019)

5. J. Yun, A copy is (not a simple) copy: Role of urban landmarks in branding Seoul as a global city. Frontiers of Architectural Research, 44-54 (2019)

6. T. Jashari-Kajtazi, A. Jakupi, Interpretation of architectural identity through landmark architecture: The case of Prishtina, Kosovo from the 1970s to the 1980s. Frontiers of Architectural Research, 480-486 (2017)

7. C. R. Bruns, B. C. Chamberlain, Landscape and Urban Planning, 296-306 (2019)

8. D. Bufquin, R. M. Back, Jeong-Yeol Park, M. Nutta, J. Dest. Mark. Man., J. Desti. Mark. \& Manag., 56-63 (2018)

9. N. Bradbury,. J.His. Geog., J. Hist. Geog., 110-111 (2015)

10. N. Benslimane, R. W. Biara, Ener. Proc., 157, 1241-1252 (2019)

11. J. Gibberd, Pro. Eng., 198, 200-211 (2017)

12. S. Moroni, Cit., 90, 2019, 42-51. (2019)

13. Z. Tang, K. Jayakar, X. Feng, H.,Zhang, X.Peng. Rachel, Identifying smart city archetypes from the bottom up: A content analysis of municipal plans (2019).

14. J. Cai, B. Huang, Y. Song, . Rem. Sen.Env., 202, 210-221 (2017)

15. P. Zhao, J. Diao, S. Li, Hab. Int., 66, 95-105 (2017) 